\title{
PRZESTĘPSTWA Z NIEWIEDZY LUB ZAPOMNIENIA
}

\section{WPROWADZENIE DO PROBLEMATYKI}

Problematyka przestępstw z niewiedzy lub zapomnienia wiąże się z odniesieniem stanu świadomości, jak też woli sprawcy, do czynników warunkujacych odpowiedzialność karną i przyczyn, dla których stosuje się instrumenty prawa karnego - przy uwzględnieniu pewnych zakłóceń leżących u podstaw realizacji obowiązków nakładanych na sprawcę przez obowiązujące regulacje prawne. Jedna z podstaw przypisania sprawcy odpowiedzialności karnej jest ustalenie, że popełnił on czyn zabroniony przez ustawę umyślnie, a w niektórych przypadkach (alternatywnie) - nieumyślnie. Umyślność cechuje przy tym zamiar, a nieumyślność - brak zamiaru, przy czym w obu przypadkach, wyjściowo, nastawienie sprawcy do swojego zachowania i jego konsekwencji, oceniane jest po stwierdzeniu, że naruszył on tzw. reguły ostrożnego zachowania (czyli sposób postępowania powszechnie uznany za właściwy na tyle, że jak w imperatywie kategorycznym Kanta - można i należy go traktować jako normę postępowania), do których przestrzegania był on zobowiązany. W przypadku braku takiego naruszenia nastawienie sprawcy do czynu pozostaje karnoprawnie irrelewantne; treść czynu zabronionego bazuje bowiem zawsze na naruszeniu pewnej (identyfikowalnej) normy postępowania.

Wątpliwości budzić może, co w tym kontekście oznacza niewiedza lub zapomnienie sprawcy. Aby określone zachowanie mogło przyjać kształt normy postępowania, konieczne jest zrozumienie jego sensu, oparte na wyobrażeniu następstw, które wywołuje nieprzestrzeganie tak ujętej normy, a nadto przekonanie o jej słuszności, które to czynniki umożliwiają internalizację danej normy. Kara kryminalna grożąca za niewywiązanie się przez sprawcę z określonego obowiązku zawartego w normie postępowania wyrażać ma potępienie dla zachowania sprawcy, obrazowane za pomoca zadawanej mu dolegliwości. Oznacza to, że jeżeli popełnienie czynu zabronionego z niewiedzy lub zapomnienia ma wiązać się z zastosowaniem tego środka represji, to musi istnieć obowiązek posiadania przez sprawcę określonej wiedzy lub wymóg pamiętania o określonym zachowaniu w danych okolicznościach - które zostaną uznane za na tyle istotne, że niewiedzę lub zapomnienie o nich należy uznać za godne potępienia.

Podczas oceny zachowania sprawcy należy rozróżnić sferę faktyczną poddająca się weryfikacji w postępowaniu dowodowym, oraz sferę prawna, opartą na normach, których znajomość i świadomość wymogu ich stosowania w określonych okolicznościach można zakładać, a w konsekwencji domniemywać $\mathrm{u}$ indywidualnego sprawcy $\mathrm{w}$ konkretnym przypadku. Istnieje zatem możli- 
wość przyjęcia, że sprawca, będący adresatem normy postępowania, posiada określoną wiedzę pozwalającą mu prawidłowo ocenić, w jakich sytuacjach i w jaki sposób normę tę należy stosować, jak również faktyczną możliwość jej stosowania $\mathrm{w}$ tych sytuacjach (co z kolei stanowi osobną przesłankę pociagnięcia do odpowiedzialności karnej). Z tego założenia, do którego praktycznego stosowania konieczne jest określenie reguł dotyczących umożliwienia sprawcy zapoznania się z treścią normy (w postaci reguł prawidłowej legislacji ${ }^{1}$ ), można wyprowadzić domniemanie znajomości normy prawnej oraz wiedzy o tym, kiedy i jakim zachowaniem sprawca dopuszcza się jej naruszenia. Jest to swoista fikcja prawna, uwarunkowana jednak potrzebą zapewnienia bezpieczeństwa chronionym dobrom prawnym, zgodnie z która ten, kto jest zobowiązany do posiadania określonej wiedzy o swoich obowiązkach nałożonych na niego przez prawo, faktycznie wiedzę tę posiada i współtworzy ona jego decyzję o określonym zachowaniu, którym narusza on przepisy ustawy karnej.

Domniemanie tego rodzaju, na gruncie ustawowych znamion czynu zabronionego, powinno przy tym - z uwagi na przypisywaną mu funkcję ochronna - nie poddawać się obaleniu. Zachowanie sprawcy można jednak w wyjątkowych przypadkach usprawiedliwić, co dopuszcza art. 30 k.k., przenosząc badana problematykę na płaszczyznę winy. Taka sytuacja zaistnieje m.in. w razie wprowadzenia osoby, której zachowanie jest przedmiotem oceny karnoprawnej, w błąd przez osobę wyjaśniająca jej treść tych obowiązków. Jeżeli powstała w takiej sytuacji błędna interpretacja obowiąujaccych przepisów dotyczących zakresu obowiązków sprawcy (błędna, czyli odbiegająca od interpretacji odpowiedniego organu egzekwującego wykonywanie danego obowiązku) wiąże się z niezrozumieniem treści regulacji i skutkuje nieprawidłowym pojęciem o obowiązującym prawie, można przyjąć błąd co do prawa (bezprawności czynu), rozpoznawany na płaszczyźnie winy, w oparciu o przyjęcie, że sprawca chciał zachować się w określony sposób (strona podmiotowa), ale nie chciał naruszyć w ten sposób prawa (wina) ${ }^{2}$. Usprawiedliwiony błąd w takiej sytuacji, zgodnie z treścią art. $30 \mathrm{k} . \mathrm{k}$., wyłącza przestępność czynu, gdyż nie można sprawcy przypisać winy, na której m.in. przestępność ta się opiera. Jeżeli błąd dotyczy rozumienia nie samego zakresu obowiąz$\mathrm{ku}$, lecz jednego ze znamion czynu zabronionego, to błąd przenosi sprawcę w sferę nieumyślnego popełnienia czynu zabronionego. Jeżeli jednak błąd co do znamion czynu zabronionego jest usprawiedliwiony, a zatem powstał w warunkach wyłaczenia możliwości poznawczych podmiotu do takiego stopnia, że wykluczone jest postawienie zarzutów ${ }^{3}$, to na powrót przenoszony jest w sferę zawinienia (art. $28 \S 1$ k.k.).

${ }^{1}$ Szerzej na ten temat: M. Wyrzykowski, Zasada demokratycznego państwa prawnego - kilka uwag, w: M. Zubik (red.), Księga XX-lecia orzecznictwa Trybunału Konstytucyjnego, Biuro Trybunału Konstytucyjnego, Warszawa 2006, s. 256-257; a także orzecznictwo TK, m.in. wyroki: z 27 listopada 2006 r. (K 47/04), z 20 listopada 2002 r. (K 41/02); z 30 października 2001 r. (K 33/00) czy z 14 lipca 2010 r. (Kp 9/09).

${ }^{2}$ Szerzej na temat podwójnej funkcji umyślności, która inaczej kształtuje się jako element strony podmiotowej i jako element winy, m.in. J. Wessels, W. Beulke, Strafrecht. Allgemeiner Teil. Die Straftat und ihr Aufbau, C. F. Müller, Heidelberg 2005, s. 54-56.

${ }^{3}$ M. Królikowski, Komentarz do art. 28 k.k., w: M. Królikowski, R. Zawłocki (red.), Kodeks karny. Komentarz, t. 1, Warszawa 2015, s. 535-536. 


\section{PRZESTĘPSTWA Z NIEWIEDZY}

Gwarancyjna funkcja domniemania znajomości swoich obowiązków prawnych i świadomości ich naruszania w określonej sytuacji ma zapobiegać dopuszczaniu do tego, by sprawca, który nie zapoznaje się z nałożonymi na niego obowiąkami, traktowany był z punktu widzenia prawa karnego korzystniej od osoby, która rzetelnie z obowiązkami tymi się zapoznała - i w ten sposób premiowania sytuacji mniej korzystnej z punktu widzenia ochrony dóbr prawnych.

Zaproponowane wyżej ujęcie wiedzy o obowiązkach prawnych i świadomości ich naruszania pozostawia jednak otwarta kwestię ujęcia tych elementów w ramy strony podmiotowej: świadomość jest bowiem zarówno elementem umyślności, jak i tzw. świadomej nieumyślności, opartej na przyjęciu, że sprawca przewiduje możliwość popełnienia czynu zabronionego, ale nie zamierza go popełniać (art. $9 \S 2$ k.k.). Domniemanie świadomości sprawcy odnośnie do zakresu jego prawnych obowiązków nie wystarcza zatem samoistnie do odpowiedzi na pytanie, czy sprawca w konkretnym przypadku zamierzał je naruszyć, czy uczynił to niezamierzenie.

O ile świadomości, że narusza się normy prawne, można domniemywać (na podstawie obiektywnie istniejącej możliwości uzyskania wiedzy o tych normach oraz obowiązku ich przyswojenia), o tyle sfera nastawienia do spełnienia tych obowiązków może być uznana za element stanu faktycznego, który każdorazowo powinien być dowodowo wykazany w postępowaniu karnym. Prowadzi to do wniosku, że w razie prawnego obowiazku uzyskania określonego rodzaju wiedzy, której sprawca faktycznie nie uzyskał, przestępstwa te przyjmować będą zawsze formę nieumyślną (tzw. świadomej nieumyślności). Tak jednak być nie musi.

Można bowiem przyjąć, że osoba, która nie znała swoich obowiązów, gdyż nie zapoznała się z nimi, nie była w stanie stwierdzić, czy chce czy nie chce dokonać ich naruszenia, co sytuuje ja w sferze obojętnego podejścia do tych obowiązków, a zatem godzenia się na to, że może je naruszyć. Gdyby bowiem, mając (domniemywana) świadomość wiążących go obowiązków, sprawca nie miał zamiaru ich naruszenia, powinien dać temu jakiś wyraz, czego jednak nie uczynił. Domniemanie świadomości swoich obowiązków pociąga zatem za soba przyjęcie godzenia się przez sprawcę na ich naruszenie, w przypadku gdy do ich naruszenia faktycznie dojdzie, a zatem domniemanie umyślności ( $\mathrm{w}$ formie zamiaru ewentualnego) po stronie sprawcy.

Należy jednak zaznaczyć, że taki sposób rozumowania naznaczony jest istotną wątpliwością co do tego, czy zamiar ewentualny to rzeczywiście obojętność - koncepcja taka pojawiła się zarówno w polskim, jak i niemieckim prawie karnym ${ }^{5}$. Nie została jednak powszechnie przyjęta, chociażby dlatego,

\footnotetext{
${ }^{4}$ Koncepcję zamiaru ewentualnego jako obojętności (neutralności woli) względem realizacji znamion czynu zabronionego reprezentował w literaturze polskiej W. Wolter. Por. W. Wolter, Nauka o przestęstwie, PWN, Warszawa 1973, s. 127.

${ }^{5}$ Szerzej na temat stanowisk reprezentowanych w tym zakresie w prawie polskim i niemieckim: M. Kowalewska, Zamiar ewentualny $w$ świetle psychologii, maszynopis rozprawy doktorskiej, Poznań 2014, repozytorium.amu.edu.pl, s. 57-78; J. Wessels, W. Beulke, s. 84-88.
} 
że w istocie abstrahuje od stanu faktycznego, w którym sprawca zwykle nie zamierza naruszyć swoich (faktycznie znanych lub nieznanych mu) obowiązków, lecz co najwyżej wykazuje ignorancję lub daleko idący optymizm w zakresie tego, że sprawy bezpiecznie potoczą się swoim torem, bez angażowania go $\mathrm{w}$ sytuacje problemowe ${ }^{6}$. Z drugiej strony karalność w przypadku większości przestępstw opartych na niewywiązywaniu się ze swoich obowiązków wymaga umyślności po stronie sprawcy. Pogodzenie ochronnego charakteru tych regulacji z akceptowalnym ujmowaniem zamiaru po stronie sprawcy wymaga w tej sytuacji przyjęcia, że - wobec szczególnej wagi obowiązków, które zostały uregulowane prawnie - niezastosowanie się do nich oznacza, z uwagi na (domniemywana) wiedze o ich istnieniu i wobec ich niewykonania, że sprawca godził się na ich naruszenie. Dopiero stwierdzenie zaistnienia po stronie sprawcy błędu co do stanu faktycznego w zakresie ich stosowania może uzasadniać przyjęcie, że naruszone zostały w drodze (świadomej) nieumyślności.

Zamiar (wiedza i wola bądź akceptacja) mogą być domniemywane w odniesieniu do naruszenia obowiązków prawnych, ale nie w odniesieniu do elementów stanu faktycznego, które nie tworzą samoistnie szczególnych prawnych obowiązków po stronie sprawcy. Przykładowo każda osoba z założenia (kształtującego domniemanie) wie, że będąc rodzicem, ma (szczególny prawny - wynikający z regulacji Kodeksu rodzinnego i opiekuńczego) obowiązek troski o dobro, w tym bezpieczeństwo, swojego dziecka; może jednak w konkretnej sytuacji nie wiedzieć o tym, że jest rodzicem danego dziecka. Każda osoba, która podejmuje się bycia członkiem zarządu spółki kapitałowej, z założenia (kształtującego domniemanie) wie, że jeżeli spółka ta stanie się niewypłacalna, to osoba ta powinna niezwłocznie (w ciagu 14 dni od daty wystapienia niewypłacalności) złożyć wniosek o ogłoszenie jej upadłości. Może jednak w konkretnym przypadku nie wiedzieć (np. z uwagi na wadliwe prowadzenie dokumentacji księgowej i prawnej spółki przez inną osobę), że spółka, która zarządza, znajduje się w stanie niewypłacalności. Okoliczności dotyczące faktów (a nie wynikające z przepisów prawa), niezbędne do przypisania sprawcy określonej formy strony podmiotowej wymagaja zatem udowodnienia.

Należy mieć również na uwadze, że zakres obowiązków prawnych objętych domniemaniem umyślności jest zróżnicowany - istnieją obowiązki związane z instytucją gwaranta: obowiązki, które odnoszą się do osób w określonej sytuacji życiowej (np. zobowiązanych do opieki nad osobą nieporadną z różnych względów - małoletnia, wiekowa, niepełnosprawna) czy wiążą się z podjęciem przez sprawcę wykonywania określonych zawodów lub zajmowania stanowiska (np. członka zarządu spółki kapitałowej). Istnieją również obowiązki powszechne, które odnoszą się do wszystkich osób (jak udzielenie pomocy w rozumieniu art. 162 k.k.). Wskazane wyżej rozróżnienie dotyczące strony podmiotowej należy przenieść odpowiednio na obowiązki powszechne - można

${ }^{6}$ W literaturze zwrócono także uwagę, że ocena, czy przypuszczenie, że sprawca uniknie popełnienia czynu zabronionego, jest bezpodstawne czy nie, jest kwestią wartościowania, a czynniki mające służyć rozróżnieniu zamiaru ewentualnego od świadomej nieumyślności opierają się głównie na zdefiniowaniu tej drugiej, co nierzadko pozbawia zamiar ewentualny własnej treści. Por. M. Kowalewska, Zamiar ewentualny..., s. 78, 139-142. 
zatem stworzyć domniemanie, że każdy wie o obciążających go obowiązkach powszechnych (jak wskazany wyżej obowiązek udzielenia pomocy w warunkach określonych w art. 162 k.k.). Jednakże już wiedza o zaistnieniu zdarzenia, w ramach którego uaktualnia się określony obowiązek (znajdowaniu się innej osoby w sytuacji określonej w art. $162 \mathrm{k} . \mathrm{k}$.), pozostaje kwestia stanu faktycznego, wymagajacego ustalenia w postępowaniu dowodowym, prowadzonym w konkretnej sprawie.

Powyższe uwagi dotyczą w pierwszej kolejności przestępstw bezskutkowych, w których (domniemany) zamiar rozciaga się na samo zachowanie sprawcy (z którym wiąże się naruszenie jego obowiązków). Świadomość i godzenie się na naruszenie swoich obowiązków nie muszą natomiast rozciagać się na zamiar spowodowania określonych skutków. Konstrukcja taka znana jest już prawu karnemu pod pojęciem strony podmiotowej kombinowanej (wcześniej: winy kombinowanej), uregulowanej w art. $9 \S 3 \mathrm{k} . \mathrm{k}$. Wydaje się zatem, że o ile sprawca z założenia zna swoje obowiązki i naruszając je, godzi się na popełnienie czynu zabronionego, o tyle przewidywania co do następstw jego zachowania nie należy już domniemywać - i w tym zakresie, na ile jest to zgodne ze stanem faktycznym, można przyjaćc, że skutek, jeśli należy do znamion czynu zabronionego, objęty jest już jego nieumyślnością. Domniemania w prawie karnym nie należy bowiem rozciagać zbyt daleko poza zakres samego zachowania sprzecznego z prawem. Zatem sprawca, który popełni czyn zabroniony wskutek nieznajomości swoich szczególnych obowiązków nałożonych na niego przez przepisy prawa, czyn ten popełni umyślnie (w wyniku przyjęcia, że zna on odpowiednie regulacje podane do wiadomości publicznej, a zatem w konsekwencji bardziej powszechnego domniemania znajomości prawa). Jeżeli jednak zachowanie sprawcy wiąże się z wywołaniem określonych skutków, również należących do ustawowych znamion czynu zabronionego, to skutek ten jest już objęty jego nieumyślnością. Dla klarowności przedmiotowej analizy należy wskazać, że skutek jest przez autorkę rozumiany jako obiektywna zmiana w rzeczywistości, odrębna od samego zachowania - i nie należy do tej kategorii znamię zagrożenia (tzw. narażenia na niebezpieczeństwo) dóbr prawnych ${ }^{7}$.

Osobną kwestią jest przestępstwo z niemożności zastosowania się do określonych (w założeniu znanych sprawcy) obowiązków, z uwagi na brak umiejętności pozwalających na wywiązanie się z nich przez sprawcę (np. z uwagi na brak właściwego przeszkolenia). W takim przypadku odpowiedzialność przesuwana jest zwykle do sfery oceny, czego od sprawcy można było oczekiwać w momencie poddanym ocenie prawnej, i ustalenia, dlaczego nie nabył określonych umiejętności oraz czy był w stanie to zrobić. Może to spowodować brak odpowiedzialności karnej za czyn z uwagi na (indywidualna) niemożność zachowania zgodnego z prawem i przeniesienie odpowiedzialności na podmiot, który zobowiązany był umożliwić sprawcy wywiązanie się przez niego ze stawianych przed nim obowiązków - za zaniechanie, którego w ramach swoich obowiązków dopuścił się z kolei ten podmiot.

7 Szerzej na ten temat: E. Hryniewicz, Skutek w prawie karnym, „Prokuratura i Prawo” 2013, nr 7-8, s. 108-125. 


\section{PRZESTĘPSTWA Z ZAPOMNIENIA}

Problem podobny do opisanego w pierwszej części tego opracowania wiąże się z tzw. przestępstwami z zapomnienia. W tym przypadku wprawdzie nie ma wątpliwości co do tego, że sprawca zna swoje obowiązki, jakie nakładaja na niego przepisy prawa - a zatem wyprowadzenie tej wiedzy z domniemania znajomości prawa nie jest potrzebne. Następuje jednak zakłócenie w uświadomieniu sobie momentu, w którym powinny być one realizowane - i w związku z tym (niejako wtórna) wątpliwość w zakresie strony podmiotowej.

Propozycje ujęcia problematyki przestępstw z zapomnienia w kategoriach karnoprawnych pojawiły się w literaturze już kilkukrotnie. W latach siedemdziesiątych XX w. Małgorzata Król-Bogomilska wskazywała, że wśród przestępstw z zapomnienia można wyróżnić: te, które zostały popełnione w wyniku świadomego nieostrożnego zachowania, polegającego na zaniedbaniu wykonywania swoich obowiązków, skutkującego zapomnieniem, oraz te, przy których zapomnienie (tudzież zachowanie będące rezultatem zapomnienia) jest jedynym naruszeniem zasad ostrożności. Do pierwszej grupy autorka zaliczyła m.in. wprowadzenie się $\mathrm{w}$ stan nietrzeźwości przez osobę obowiązaną do dbania o bezpieczeństwo innych osób, skutkiem czego zapomniała ona podjąć czynności niezbędnych do ochrony ludzkiego życia (nietrzeźwy dróżnik PKP na strzeżonym przejeździe kolejowym). Do drugiej - zapomnienie zabezpieczenia substancji łatwopalnej przed wybuchem czy spowodowanie pożaru wskutek zapomnienia wyłączenia żelazka ${ }^{8}$. W przypadku pierwszej z wyróżnionych grup przestępstw z zapomnienia Król-Bogomilska postulowała przyjęcie odpowiedzialności za lekkomyślność jako formę zapomnienia zawinionego przez sprawcę ${ }^{9}$, który musiał zdawać sobie sprawę, że naruszając zasady ostrożności, może popełnić czyn zabroniony, choć z pewnością tego nie chciał. W przypadku drugiej grupy przestępstw z zapomnienia, kiedy to zapomniano o samych zasadach ostrożności i sprawca nie zdawał sobie sprawy, że popełnia właśnie czyn zabroniony, krytycznie analizując możliwość weryfikacji, czy sprawca powinien uświadomić sobie, że popełnia czyn zabroniony - postulowała ona bezkarność sprawcy. W tym bowiem przypadku zapomnienie nabiera „ludzkiego” charakteru (tego, co zdarzyć się może każdemu, i stąd trudno jednostce robić z tego zarzut), a ewentualna kara traciła znaczenie prewencyjne - nie mogła bowiem sprawić, by na przyszłość potencjalni sprawcy mieli lepszą pamięć. Stąd autorka sugerowała zastapienie w takich przypadkach karania środkami mogącymi ułatwiać zapamiętywanie (np. prowadzenie szkoleń uświadamiających w sposób obrazowy negatywne skutki zapomnienia) czy wprowadzaniem instrumentów mogących ograniczać negatywne skutki zapominania (jak samoczynnie wyłączające się żelazka $)^{10}$.

${ }^{8}$ M. Król-Bogomilska, Odpowiedzialność karna za przestęstwa popetnione wskutek zapomnienia, ,Zeszyty Naukowe IBPS” 1979, nr 12, s. 62-63.

${ }^{9} \mathrm{Na}$ temat przesuwania elementów tworzących lekkomyślność do sfery winy, szerzej: Ł. Pohl, Btad co do okoliczności stanowiqcej znamię czynu zabronionego w polskim prawie karnym (zagadnienia ogólne), Wyd. Ars boni et aequi, Poznań 2013, s. 41.

${ }^{10}$ M. Król-Bogomilska, op. cit., s. 68-78. 
W świetle takiego ujęcia problematyki przestępstw z zapomnienia można byłoby uznać, że zapomnienie przyjmować będzie formę lekkomyślności głównie przy przestępstwach skutkowych - gdzie wystapienie skutku jest wynikiem niezastosowania się do zasad ostrożności. Bezkarność wiązać się będzie natomiast głównie z przestępstwami bezskutkowymi, w których dokonanie będzie utożsamiane $\mathrm{z}$ naruszeniem zasad ostrożności przez zapomnienie. Jednak przykłady podane przez przywoływana autorkę, intuicyjnie trafne, przeczą tej tezie. Przypisanie sprawcy lekkomyślności (czy też odtworzenie takiego jego nastawienia do czynu zabronionego) wiąże się z przyjęciem, że sprawca nie chciał popełnić czynu zabronionego (choć dopuszczał możliwość jego powstania), niezależnie od jego konstrukcji. Czyn ten jednak zaistniał, co rodzi kwestię przypisania sprawcy nie tylko samego skutku, lecz w ogóle odpowiedzialności za spowodowanie czynu zabronionego i postawienie mu na tej podstawie zarzutu. Król-Bogomilska wskazała, że nie w każdym przypadku zapomnienia, z którego wyniknął czyn zabroniony, można sprawcy taki zarzut postawić. Stanowisko to jest trafne przy założeniu, że brak możliwości przypisania odpowiedzialności ograniczony zostanie do stosunkowo niewielu sytuacji o charakterze wyjątkowym, z uwagi na ich nieprzewidywalność - i to nie w zakresie następstw zachowania sprawcy, lecz sytuacji, w której sprawca się znajdzie i przyczyn, dla których pojawi się luka pamięciowa. Jeżeli sprawca spowoduje pożar, gdyż zapomni wyłączyć żelazko - następstwa są łatwe do przewidzenia i przypisanie strony podmiotowej nie będzie problematyczne. Przypisanie samej odpowiedzialności karnej będzie jednak różnić się w sytuacji, w której stan ten spowodowany został informacją o zdarzeniu wywołującym silną reakcję emocjonalną (np. o śmierci osoby najbliższej), oraz w sytuacji, w której stan ten nie może być usprawiedliwiony taką szczególną sytuacja (lecz wynika np. z roztargnienia sprawcy). Z tej perspektywy przestępstwa z zapomnienia budzą wątpliwości nie w zakresie kwalifikacji prawnej, lecz w kwestii możliwości przypisania winy ich sprawcy - i na tej podstawie egzekwowania jego odpowiedzialności karnej.

W latach osiemdziesiątych XX w. krótki przyczynek do dyskusji na temat tego, jak zapomnienie „styka się z norma prawa karnego”, opublikował Władysław Wolter. Samo zapomnienie określił on jako: „zahamowanie rekonstrukcji jakiejśs myśli przekazanej do pamięci”, a problem sprowadził do zrównania zapomnienia z nieświadomościa, wskazując, że: „tam gdzie jest świadomość, nie ma miejsca dla zapomnienia”, a „zapomnienie to nieprzewidywanie”. Wszystkie formy zapomnienia zostały zatem przez tego autora zakwalifikowane jednolicie - jako podstawa do przyjęcia odpowiedzialności karnej za przestępstwo nieumyślne $-\mathrm{i}$ to $\mathrm{w}$ formie niedbalstwa ${ }^{11}$.

W latach dziewięćdziesiątych XX w. powrócono w literaturze do analizy problematyki przestępstw z zapomnienia jako przestępstw, „przy których wypełnienie znamion czynu zabronionego jest wynikiem wystapienia u sprawcy zakłóceń pamięci"12; wskazywano, że nie jest to grupa jednolita - przyczyny zapomnienia i obowiązki nakładane na sprawcę, wymagające zapamiętania,

11 W. Wolter, Oceny prawnokarne zapomnienia, „Państwo i Prawo” 47, 1985, z. 5, s. 43-44.

12 A. Chmiel, Kilka uwag o tzw. przestepstwach z zapomnienia, „Palestra” 1991, nr 3-4, s. 10. 
mogą być bowiem różne, skutkując różną kwalifikacją prawną. Sprawca może być w szczególności zobowiązany (z mocy prawa lub na gruncie obowiązków, jakie sam na siebie przyją) do posiadania określonych kwalifikacji, odpowiedniego utrwalenia pewnego materiału czy posiadania doświadczenia, które mają eliminować niebezpieczeństwo zapomnienia, jak należy się zachować $\mathrm{w}$ danej sytuacji. Sprawca powinien zatem zorganizować się w taki sposób, by wyłączyć lub zminimalizować ryzyko zapomnienia - i to na tym etapie, a zatem niejako na przedpolu samego czynu zabronionego, analizowany powinien być problem przypisania mu winy za przestępstwa z zapomnienia ${ }^{13}$. Tu także zapomnienie utożsamiono z nieumyślnością, a problem przypisania odpowiedzialności przeniesiono na płaszczyznę winy, nawiązując do koncepcji zawinienia na przedpolu czynu zabronionego (niem. Vorverschulden) ${ }^{14}$.

Zaprezentowane wyżej spojrzenie na przestępstwa z zapomnienia podkreśla wagę zakotwiczenia w normie prawnej swoistego „obowiązku pamiętania” (będącego $\mathrm{w}$ istocie nakazem podjęcia wymaganych starań, aby wywiązać się z obowiązku określonego w przepisach prawa). Norma prawna kształtuje bowiem charakter obowiązku, który ustanawia. Jako regulacja podawana do powszechnej wiadomości norma prawna tworzy swoiste domniemanie, że sprawca - znając prawo - zna treść normy (choć niekoniecznie uświadamia sobie w danej chwili jej treśćc ${ }^{15}$ ), a nie dokładając starań, by zachować się zgodnie z jej treścia - akceptuje możliwość jej naruszenia. Na tej podstawie można zatem domniemywać umyślność jego zachowania, podczas gdy w pozostałych przypadkach dotyczących reguł ostrożności, odtwarzanych bez wsparcia przepisów ustawy, konieczne jest wykazywanie (dowodowe) lub wnioskowanie, że sprawca powinien (jeśli mógł) uświadomić sobie daną regułę ostrożności. Norma prawna nakładająca określony obowiązek skraca w ten sposób proces ustalania strony podmiotowej u sprawcy. Problem prawnego uzasadnienia przyjętej w takim przypadku umyślności zostaje przeniesiony do sfery domniemania, a kwestia rozbieżności czasowej winy i czynu zostaje uregulowana w ramach możliwości uniknięcia zaistnienia danego stanu rzeczy, a zatem w ramach wspomnianego zawinienia na przedpolu czynu zabronionego. Instytucja ta znana jest prawu polskiemu chociażby z przestępstw popełnianych w warunkach nietrzeźwości, do których odnosi się regulacja z art. 31 § 3 k.k.

Po 2000 r. pojawiły się jeszcze dwa przyczynki do dyskusji nad kwestią zapomnienia w prawie karnym, z czego jeden bez chęci umieszczenia go w ramach

13 Ibidem, s. 11-12.

14 Szerzej na temat Vorverschulden i jego odniesienia do koncepcji action libera in causa, m.in. T. Lenckner, w: A. Schönke, H. Schröder (red.), Strafgesetzbuch. Kommentar, C. H. Beck, München 1991, [Komentarz do $§ 20$ StGB], s. 318-319; T. Tröndle, Strafgesetzbuch und Nebengesetze, C. H. Beck, München 1997, s. 150-152.

15 Por. wskazane w literaturze rozróżnienie pomiędzy treścią świadomości (czyli posiadaną wiedza, niezależnie od tego, czy w danym momencie jest zaktualizowana w procesie myślenia) i jej przedmiotem (czyli tym, co aktualnie zajmuje myśli). Na tej podstawie przyjmuje się, że o ile fakt zachowania sprawcy stanowić powinien przedmiot świadomości, o tyle w pozostałym zakresie znamiona mogą być objęte treścią świadomości (czyli ogólniej ujętą wiedza). Na etapie kwalifikacji prawnej zachowania sprawcy nie jest także konieczne uświadamianie sobie przez niego bezprawności jego czynu - a jedynie faktu i kierunku podjęcia określonego zachowania. Por. Ł. Pohl, op. cit., s. 104-107. 
karnoprawnej dyskusji nad tym problemem. Jego autor, analizując psychologiczne podstawy zjawiska zapominania, wskazał na złożoność problematyki przypisania sprawcy na tej podstawie winy. Zapomnienie może być bowiem skutkiem zarówno tego, na co sprawca może mieć wpływ (podejmowanie określonych czynności mimo zmęczenia, zdenerwowania, braku wystarczających kwalifikacji, w warunkach zbiegu zadań wywołujących dekoncentrację), jak i tego, na co wpływu może nie mieć (presja społeczna, przeciążenie informacjami, manipulacja jego pamięcią przez osoby trzecie). Możliwość wpłynięcia przez sprawcę na warunki, w jakich dopuścił się zapomnienia, powinna zatem wpływać na kwestię przypisania mu winy - co nawiąuje do zaprezentowanej wyżej koncepcji Król-Bogomilskiej ${ }^{16}$.

Najnowsze stanowisko wyrażone ostatnio w literaturze stanowi pewną próbę umiejscowienia problematyki zapomnienia w kontekście przyjętych schematów prawnych z uwzględnieniem spojrzenia psychologa ${ }^{17}$. Autorka zwraca w nim uwagę, że zapomnienie o określonym obowiązku zwykle oznacza niemożność przewidzenia, że popełni się w wyniku tego czyn zabroniony, co wyklucza odpowiedzialność karną ${ }^{18}$. Uwzględniając wcześniejsze rozwiązania w tym przedmiocie, autorka dochodzi ostatecznie do wniosku, że możliwe sa zarówno przypadki nieświadomej nieumyślności pośród sytuacji, w których zapomnienie dotyczy tego, co sprawca powinien był zrobić, jak i świadomej nieumyślności - gdy pojawia się ono w procedurze wykonywania określonej czynności ${ }^{19}$.

Choć poszczególni wskazani wyżej autorzy, którzy analizowali problematykę przestępstw opartych na zapomnieniu, różnią się w podejściu do tego, w jakich przypadkach tego rodzaju przestępstw należy przyjaćc odpowiedzialność karna za lekkomyślność ('świadomą nieumyślność), a kiedy za niedbalstwo (nieświadomą nieumyślność), to jednak są zasadniczo zgodni co do tego, że przy tego rodzaju przestępstwach niezależnie od kontekstu, w jakim zapomnienie prowadzi do wypełnienia ustawowych znamion czynu zabronionego, nie można przyjąć zaistnienia przestępstwa umyślnego. W ocenie tych autorów zapomnienie może być rozpatrywane tylko w kontekście naruszenia obowiązku ostrożności, przy założeniu, że skoro sprawca zapomniał o danym obowiązu, to nie sposób uznać, że chciał go naruszyćc ${ }^{20}$. Już wyżej wskazano jednak, że przyjęcie umyślności przy tego rodzaju przestępstwach wydaje się możliwe.

Wydaje się również, że praktyka skłonna będzie podejść do kwestii popełnienia przestępstwa będącego wynikiem zapomnienia bardziej restrykcyjnie, przypisując sprawcy w niektórych przypadkach właśnie umyślność, choć raczej w zamiarze ewentualnym niż bezpośrednim. Pewne przestępstwa sa wszak wprost „stworzone” do tego, by popełniać je z zapomnienia - zapomnieć można o podaniu urzędowi skarbowemu podstawy opodatkowania, wystawieniu faktury za wykonaną i opłaconą już usługę, wpisania faktu dokonania

${ }^{16}$ B. Bielski, Gdy sqd styszy „nie pamiętam”, „Prokuratura i Prawo” 2005, nr 2, s. 130-138; podobnie M. Król-Bogomilska, op. cit., s. 69 i 74.

17 M. Kowalewska, Przestepstwa z zapomnienia, „Prokuratura i Prawo” 2015, nr 3, s. 63-85.

18 Ibidem, s. 83.

19 Ibidem, s. 84-85.

${ }^{20}$ A. Chmiel, op. cit., s. 14; M. Kowalewska, Przestepstwo z zapomnienia, s. 80. 
usługi i otrzymania za nią wynagrodzenia do ksiag rachunkowych, wpisania niektórych wymaganych danych do oświadczenia majątkowego czy podania niekorzystnych informacji o określonym zdarzeniu w trakcie składania zeznań. O ile kwestia zapominania jest sprawą indywidualna, na którą - na co zwraca się uwagę w psychologii - jednostka może mieć wpływ, w szczególności wypierając z pamięci nieprzyjemne zdarzenia ${ }^{21}$, to jednak wydaje się, że konsekwentne wychodzenie z założenia, że sprawca ma prawo pewnych faktów nie pamiętać, prowadziłoby w niektórych sferach życia, w tym w sferze obowiązków prawnych (m.in. podatkowych), do akceptacji naruszania nałożonych na jednostkę obowiązków w wyniku okoliczności częściowo od niej zależnych, jak zorganizowanie ich wykonywania tak, by o nich pamiętać. Ponadto sfera strony podmiotowej, w która zapamiętywanie jest wpisane, może być odtwarzana jedynie za pomoca narzędzi pomocniczych (niejako „poszlakowych”), na podstawie innych okoliczności przyjmujących jakiś zewnętrzny wyraz - i wydaje się, że częściej ma charakter przypisywania sprawcy określonego nastawienia do czynu zabronionego niż odtwarzania go. Wymaga to stosowania pewnych form wnioskowania, a także założeń, w tym domniemań, o charakterze konstrukcji prawnych, które pozwolą na przypisanie sprawcy, stosownie do okoliczności, określonego nastawienia, nawet dopuszczając pewne odstępstwa od stanu faktycznego (które można jednak zwykle starać się wykazywać logicznie i dowodowo).

Przestępstwa z zapomnienia można zatem rozumieć w ten sposób, że sprawca zna treść regulacji prawnych, interpretuje je prawidłowo i jest świadomy tego, że kształtują one jego sytuacje prawna, jednak w konkretnym czasie, w którym nie wywiązał się ze swoich obowiązków, chwilowo nie uświadomił sobie, że obowiązek ten należy zrealizować. Jest to zatem swoisty przypadek nieświadomości popełnienia $\mathrm{w}$ danym momencie czynu bezprawnego, wynikającej stąd, że sprawca nie zapewnił sobie instrumentów, które umożliwiłyby mu przypomnienie, w odpowiednim czasie, o aktualizacji ciążącego na nim obowiązku określonego zachowania we właściwym czasie. Sprawca winny jest zatem (czyli można mu zrobić zarzut) złej organizacji swoich obowiązków, skutkującej pominięciem wykonania jednego z nich. Ponieważ sprawca zna swoje obowiązki i czas ich wykonania, a jedynie przejściowo w wyniku okoliczności leżących po jego stronie i poddających się jego kontroli ich nie wykonuje, więc można przyjąć umyślność niewykonania tego obowiązku, choć - podobnie jak w przypadku przypisania zamiaru sprawcy popełniającemu czyn zabroniony w warunkach nietrzeźwości - następuje tu swego rodzaju przesunięcie momentu decyzyjnego na czas swoistego „stworzenia warunków” do popełnienia czynu zabronionego. W tej sytuacji ewentualna usprawiedliwiona przyczyna zapomnienia, obiektywnie mogąca utrudniać pamiętanie (jak osobista tragedia), wykluczy dopiero świadomość bezprawności czynu, a zatem zawinienie sprawcy.

Takie ujęcie nie stoi w sprzeczności z dokonanym wyżej określeniem zapomnienia jako swoistego przypadku (chwilowej, przejściowej) nieświadomości, że sprawca popełnia czyn bezprawny. Wprawdzie sprawca w momencie po-

${ }^{21}$ B. Bielski, op. cit., s. 133. 
pełnienia czynu bezprawnego nie miał woli jego popełnienia ani też w żaden inny sposób nie ustosunkowywał się do możliwości jego popełnienia, gdyż nie uświadamiał sobie, że właśnie aktualizuje się jego prawny obowiązek działania w określony sposób. Samo zachowanie było jednak świadome i zamierzone. Brak właściwej organizacji umożliwiającej sprawcy uświadomienie sobie faktu bezprawności czynu we właściwym czasie stanowi przykład niezachowania ostrożności wymaganej w danych okolicznościach w sytuacji, w której popełnienie czynu przez zapomnienie było przewidywalne. Niezachowanie wymaganej ostrożności stanowi przekroczenie normy postępowania i punkt wyjścia zarówno do normatywnego (obiektywnego) przypisania należącego do znamion skutku do przestępnego zachowania, jak i podstawę przypisania odpowiedzialności karnej jako takiej. Jeśli przyjmiemy, że zastosowanie tu znajdzie zasada domniemania znajomości obowiązków prawnych, przekładająca się na przyjęcie, że sprawca, który zna swoje obowiązki i nie stosuje się do nich, co najmniej godzi się - wobec niezapewnienia sobie właściwej organizacji swoich obowiązków - na to, że któryś z tych obowiązków nie zostanie spełniony, przestępstwo nabiera charakteru umyślnego i jako takie można je przypisać jego sprawcy.

Naturalnie również w tym przypadku istnieje wymóg udowodnienia zamiaru w zakresie faktów przekładajacych się na znamiona czynu zabronionego i przewidzenia możliwości ich realizacji. Oznacza to, że jeżeli sprawca w prawidłowy sposób zorganizował swoje obowiązi, np. wyznaczając kompetentna osobę, która zastapi go w ich realizacji (w przypadku, w którym wykonanie obowiązku może być przeniesione na inną osobę), a osoba ta nie wywiąże się z przyjętego obowiązu, sprawca będzie odpowiadał karnie jedynie w granicach zapewnienia właściwego nadzoru w zakresie ich wykonania. Może to skutkować przyjęciem, że czyn zabroniony popełnił nieumyślnie, a nawet - w razie zapewnienia prawidłowego nadzoru ze swojej strony - że nie zaszedł nawet przypadek nieumyślnego zachowania. W zakresie niewypełnienia (wskutek zapomnienia) własnych obowiązków nałożonych na sprawcę regulacją prawną jego zachowanie pozostanie umyślne.

\section{PODSUMOWANIE}

Sposób rozpoznawania przyczyny wadliwości zachowania sprawcy i odpowiedniego zakwalifikowania konkretnego przypadku zależy od tego, w jakiej płaszczyźnie umieszczony zostanie obowiązek sprawcy - czy będzie to płaszczyzna czynu (niemożność wywiązania się ze swoich obowiązków), jego zabronionego charakteru (skutkując przyjęciem domniemania w zakresie znajomości prawa i prowadzeniem postępowania dowodowego w zakresie faktów) czy winy jego sprawcy (zarzucalności niewiedzy, błędnej interpretacji lub zapomnienia sprawcy).

Popełnienie czynu zabronionego może być wynikiem braku faktycznej możliwości wywiązania się z obowiązków nałożonych na jego sprawcę. Jeżeli ta niemożność wynika z braku umiejętności nienabytych z przyczyn niezależnych od sprawcy, to brak podstaw do poteppienia jego zachowania przez pry- 
zmat przypisania sprawcy odpowiedzialności karnej oraz stosowania względem niego represji karnej. Niemożność zachowania zgodnego z prawem, ujmowana wskazaniem, że impossibilium nulla obligatio est, to płaszczyzna czynu, a ewentualne podejmowanie mimo tego czynności służących ochronie dobra prawnego rozpatrywane jest $\mathrm{w}$ kategorii optymalizacji zachowania sprawcy w sytuacji, w jakiej się znalazł, z punktu widzenia ochrony tego dobra.

Popełnienie czynu zabronionego może wynikać z nieznajomości obowiązków, jakie w danym systemie prawnym ciążą na wszystkich osobach lub na określonej grupie osób. Jeżeli obowiązki te mogą zostać ujęte w ramy prawne, to istnieje domniemanie ich znajomości przez adresatów tych obowiązków (wynikające z ogólnego domniemania znajomości prawa) i podejmowania zachowań przy uwzględnieniu posiadanej wiedzy. Ewentualny usprawiedliwiony błąd co do prawa (w zakresie kształtującym bezprawność czynu), w szczególności wynikający z uzasadnionej okolicznościami odmiennej niż w przypadku organów egzekwujących przestrzeganie prawa wykładni obowiązujących regulacji, analizowany jest na płaszczyźnie winy jako przesłanka ewentualnej rezygnacji z postawienia sprawcy zarzutu naruszenia prawa. Natomiast w zakresie znamion dotyczących stanu faktycznego konieczne jest ich stwierdzenie w postępowaniu dowodowym, chyba że ich zaistnienie wynika z wiedzy powszechnej czy logicznego wnioskowania dotyczącego nastawienia sprawcy do podejmowanego zachowania.

Zapomnienie zakłada już natomiast wiedzę sprawcy co do swoich obowiązków i prawidłowe ustalenie ich treści, przy jednoczesnym nieuświadomieniu sobie w wymaganym czasie, że należy je zrealizować. Tu również obowiązuje zasada domniemania znajomości obowiązków prawnych i, co do zasady, wymóg stwierdzenia zamiaru w odniesieniu do stanu faktycznego. Ponieważ jednak sprawca dysponuje zwykle wystarczajacca ilością czasu pozwalająca mu na właściwe zorganizowanie się w taki sposób, by zapewnić wykonanie obowiązku we właściwym czasie - przez siebie bądź przez inną osobą zdolna do zastapienia go, zasadnie można przyjąć, że nie dochowując należytej staranności w tym zakresie, co najmniej godzi się na to, że obowiązek ten nie zostanie wykonany. Wprawdzie nastawienie do swojego czynu obejmujące godzenie się na jego popełnienie $\mathrm{w}$ zakresie, $\mathrm{w}$ jakim umożliwia zrobienie sprawcy $\mathrm{z}$ tego zarzutu, wiąże się z faktycznym przesunięciem czasowym. Niemniej ponieważ strona podmiotowa jest $\mathrm{w}$ istocie pewna konstrukcją prawna, oparta na przypisaniu sprawcy określonego nastawienia w danych warunkach, wydaje się, że przyjęcie zamiaru nie ogranicza się do stwierdzenia, że sprawca w danym momencie świadomie zdecydował się na popełnienie czynu zabronionego, lecz że w warunkach, które obejmował swoją świadomością i akceptacja dopuścił do realizacji zachowania uzupełniającego znamiona czynu zabronionego - nawet jeżeli na dany moment nie zdawał sobie sprawy z bezprawności swojego zachowania.

Zasadniczo różna jest zatem sytuacja prawna i możliwość wyłączenia odpowiedzialności karnej w przypadku sprawcy, który nie składa w wymaganym terminie właściwej deklaracji podatkowej bądź nie umieszcza wymaganych składników majątku w oświadczeniu majątkowym, działając jako zobowiązany 
do tego funkcjonariusz publiczny. Jeżeli sprawca nie wie o takim obowiązku, okoliczność ta pozostaje relewantna jedynie w płaszczyźnie winy, w kontekście badania usprawiedliwionej niewiedzy o tym, że trzeba wykonać dany obowiazek. Będą to sytuacje stosunkowo rzadkie i dotyczyć będa głównie (usprawiedliwionych) błędów co do interpretacji obowiązujących przepisów, gdyby ich treść dopuszczała różny wynik wykładni - i nie istniały (co wiąże się z kwestią usprawiedliwienia tego błędu) procedury jego usuwania (jak np. interpretacje podatkowe). Podobnie jeżeli sprawca zapomniał o złożeniu właściwej deklaracji podatkowej lub o umieszczeniu danych o wartościowym składniku swojego majątku w oświadczeniu majątkowym. Jeżeli sprawca, będąc świadomym ciążącego na nim obowiązku, dopuszcza do wadliwej organizacji skutkującej niewypełnieniem go we właściwym czasie, odpowiada on za umyślne naruszenie swojego obowiązku. Jeżeli jednak zadbał w należyty sposób o właściwą organizację jego wykonania, a mimo tego obowiązek nie został wykonany, to nie można mu przypisać nawet nieumyślnego popełnienia czynu zabronionego. W obu przypadkach osobną kwestią z uwagi na przyczyny zakłóceń leżących u podstaw realizacji ich obowiązków jest możliwość postawienia sprawcy na tej podstawie zarzutu (przypisania winy).

Choć zapominanie wydaje się „rzeczą ludzką”, intuicyjnie kojarzoną z nieświadomością popełniania czynu zabronionego, to wzgląd na potrzebę ochrony istotnych dóbr przez prawo karne wymaga jego ujęcia w szerszym niż krótkookresowym kontekście - takim, który wiąże się z przewidywaniem lub możliwościa przewidywania popełnienia czynu zabronionego, a nie chwilową amnezja, której przy właściwej organizacji można było zapobiec.

Podsumowując, można zatem wskazać, że popełnienie przestępstwa w wyniku niewiedzy lub zapomnienia zakłada istnienie obowiązku zastosowania się do określonej normy postępowania, która umknęła sprawcy w czasie popełnienia czynu zabronionego. Co do percepcji stanu faktycznego można się mylić - i okoliczność ta została uwzględniona w uprzednim brzmieniu art. $28 \S 1$ k.k. wyłaczającym umyślność w razie błędu co do znamion (a obecnie jest wyprowadzana $\mathrm{z}$ art. $9 \S 1$ i 2 k.k. $)^{22}$. Natomiast istniejace domniemanie znajomości przez każdego swoich obowiązów prawnych pozwala, w przypadku popełnienia przestępstw z niewiedzy, na przypisanie sprawcy fikcji prawnej w postaci świadomości tych obowiązków i godzenia się na ich naruszenie, skutkujące przyjęciem umyślnego zachowania. Podobnie umyślne są zachowania oparte na zapomnieniu. Ewentualne usprawiedliwienie ich sprawcy może mieć miejsce na płaszczyźnie winy w zakresie określonym w art. 30 k.k., który może znaleźć zastosowanie zarówno do sytuacji niewiedzy, jak i, odpowiednio, przejściowego zapomnienia o konieczności wywiązania się z określonych obowiązków leżących po stronie sprawcy.

dr Elżbieta Hryniewicz-Lach

Uniwersytet im. Adama Mickiewicza w Poznaniu

hryniew@amu.edu.pl

${ }^{22}$ Zmiana w tym zakresie została wprowadzona ustawą z 20 lutego 2015 r. o zmianie ustawy Kodeks karny oraz niektórych innych ustaw, Dz. U. 2015, poz. 396. 


\section{CRIMES ARISING FROM IGNORANCE OR FORGETFULNESS}

\section{Sum mary}

This article attempts to place crimes based on ignorance or forgetfulness in the structure of a criminal act. It also aims to establish the basis on which criminal liability may be attributed. The author proposes to classify these crimes as voluntary, which is a consequence of some presumptions, like the presumption of general knowledge of the applicable law, and the lack of unambiguous criteria for the distinction between conditional intention (dolus eventualis) and recklessness in practice. This idea enables to see the problem of the intention from a new angle, based not only on intuition, but also on the legal argumentation and interference from the evidence proceeding. 